https://doi.org/10.31516/2410-5325.065.21

UDC 725.96(64)-028](045)

N. Moutazakki, University of Hassan II Casablanca, Senior Researcher at the Faculty of Literature and Humanities, Doctor of Philosophy, Professor (Kingdom of Morocco) moutazakkinaoual@yahoo.fr

\title{
THE KSARS AND KASBAS OF MOROCCO: EXAMPLES FROM THE DRAA-TAFILALET REGION IN THE SOUTH EAST OF MOROCCO ${ }^{1}$
}

Professor Naoual Mutazakki is a cultural studies scholar, historian, local historian, specializing in the study of Moroccan culture, in particular, the architectural monuments of the country. The following materials are a summary of the presentation at the round table «Historical and cultural studies in Ukraine and Morocco» on April 19, 2019 at the Kharkiv State Academy of Culture. The object of the author's research is unique monuments of medieval Berber-Arab architecture, namely «Ksars» (fortified areas, forts) and "Kasbas» (citadels). The dependence of functionality and architectural style of buildings on a specific historical epoch, demographic structure, climatic conditions, economy, cultural and religious traditions of the region is emphasized. The current state and prospects of using attractions as tourist facilities and an incentive for economic development are considered.

Keywords: Berber-Arab architecture, ksars, kasbas.

Н. Мутазаккі, Університет Хасана II Касабланка, старший науковий співробітник факультету літератури і гуманітарних наук, доктор філософії, професор (Королівство Марокко)

\section{КСАРИ І КАСБИ МАРОККО: НА ПРИКЛАДІ РЕГІОНУ ДРА-ТАФІЛАЛЕТ (ПІВДЕННИЙ СХІД МАРОККО)}

Професор Наваль Мутазаккі - культуролог, історик, краєзнавець, спеціалізується на вивченні марокканської культури, зокрема архітектурних пам'яток країни. Наведені нижче матеріали являють собою короткий виклад презентації на засіданні круглого столу «Історико-культурні дослідження в Україні і Марокко» 19 квітня 2019 р. у Харківській державній академії культури. Об'єкт дослідження автора - унікальні пам'ятки середньовічної берберо-арабської архітектури, а саме «ксари» (укріплені райони, форти) i «касби» (цитаделі). Особливо наголошується на залежності функціональності та архітектурного стилю будівель від конкретної історичної доби, демографічної структури, кліматичних умов, економіки, культурних та релігійних традицій регіону. Розглянуто нинішній стан та перспективи використання пам'яток як туристичних принад і стимулу для економічного розвитку.

Ключові слова: берберо-арабська архітектура, ксари, касби.

1 This work is licensed under a Creative Commons Attribution-NonCommercialShareAlike 4.0 International License. 
Н. Мутазакки, Университет Хасана II Касабланка, старший научный
сотрудник факультета литературы и гуманитарных наук, доктор
философии, профессор (Королевство Марокко)

\section{КСАРЫ И КАСБЫ МАРОККО: НА ПРИМЕРЕ РЕГИОНА ДРА-ТАФИЛАЛЕТ (ЮГО-ВОСТОК МАРОККО)}

Профессор Науаль Мутазакки - культуролог, историк, краевед, специализируется на изучении марокканской культуры, в частности архитектурных памятников страны. Приведенные ниже материалы представляют собой краткое изложение презентации на заседании круглого стола «Историко-культурные исследования в Украине и Марокко» 19 апреля 2019 г. в Харьковской государственной академии культуры. Объект исследования автора - уникальные памятники средневековой берберо-арабской архитектуры, а именно «ксары» (укрепленные районы, форты) и «касбы» (цитадели). Особо подчеркивается зависимость функциональности и архитектурного стиля зданий от конкретной исторической эпохи, демографической структуры, климатических условий, экономики, культурных и религиозных традиций региона. Рассмотрено нынешнее состояние и перспективы использования достопримечательностей как туристических объектов и стимула для экономического развития.

Ключевые слова: берберо-арабская архитектура, ксары, касбы.

In this brief presentation, I will take you to the $8^{\text {th }}$ region of the 12 regions of the Kingdom of Morocco in accordance with the regional subdivisions implemented in 2012 within the framework of the project of advanced regionalization. By virtue of this project, Morocco was subdivided into 12 administrative regions, hence the birth of the Draa-Tafilalet region.

The Draa-Tafilalet region, located in the south east of Morocco, spreads over the south-eastern mountainsides of the high and Anti Atals mountains, altogether a surface area of $132.137 \mathrm{~km}^{2}$, which makes of it the second largest region nationwide. It has a population of 1.635 .008 inhabitants, with a population density of 12,37 inhabitants $/ \mathrm{km}^{2}$, distributed in an uneven and unbalanced way. The region includes five provinces, namely Errachidia (the capital or the administrative centre), Midelt, Tinghir, Ouarzazate and Zagora.

The Mountains of the high Atlas northward and the Anti Atlas southward form a natural barrier which prevents the maritime air masses from entering the oases. The geographical location results not only in low and irregular rainfall but also in a sharp temperature increase in the summer (more than $45^{\circ} \mathrm{C}$ in July and August) and a sharp temperature decrease in winter $\left(\right.$ below $0^{\circ} \mathrm{C}$ ). Face to these hard conditions, the inhabitants of these oases were forced to be creative to acclimate and adapt themselves to these harsh and severe climatic conditions, both at the level of farming crops and housing to ensure continuity. Concerning farming, the region offers plenty of farming produce adapted to the harsh climatic conditions, such as olive trees, almonds, Henna, saffron and roses. 
However, the region remains the major producer of dates, the most popular fruit worldwide, known as the "fruit of heaven". It produces $116,000.00$ tons of dates on average per year, i.e., $85 \%$ of the total national date production over a total surface area of about 45,000.00 hectare. It should be noted that date production in the past was double today's production, with over 200 types of date, including the best quality type of dates called "Al Mjhoul". The decrease in production is due to the "bayoud" palm disease. The region holds the activities of the yearly International date Fair in Erfoud. The production of these types of dates is the outcome of the existence of about 4 million palm trees along the rivers feeding the oases in the Draa-Tafilalet region, of which flow out of the High Atlas Mountains (These Rivers are Ziz, Ghris, Todgha, Draa).

Regarding housing, the "ksars and Kasbahs" constituted the main architectural and socio-cultural features of oases in the Draa-Tafilalet region, for it carries a rich historic legacy which, in turn, embodies the sacrifices, solidarity and creativity of local inhabitants as well as the extent of their links with their environment, both in terms of construction materials and designs. In other words, the architectural heritage, embodied in "Ksars" and "Kasbahs", is similar throughout the oases so much at the level of construction materials as at the level its function. All «ksars and "kasbas"» are surrounded by walls and towers, of which the height and thickness vary depending on the importance of the ksar.

Generally, ksars in the region of Draa-Tafilalet generally represent closed residences inside the farming space of the oases; they are usually square-shaped and surrounded by thick walls. These walls are 1 to 2 meters wide and between 5 and 10 meters high with square towers used as sentry spots.

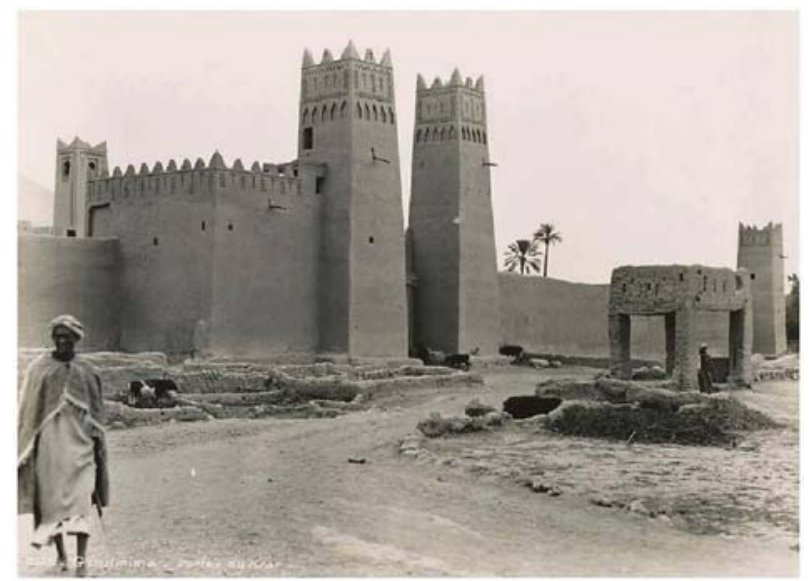

Image 1. Iglimimen Ksar in Ghris Oasis 
The building of the Ksar goes as far back as the 16th century and most of its inhabitants are Senhaja berbers known as Ait Morghad. The ksar played an important role in the Saharan trade activities. This is confirmed by the fact that in 1635, the Zawiya Dila'ia insisted that this Ksar remain under its control as a condition to stop its conflict with the Hassani Cherifiens of Sijilmassa (the Alawite dynasty of Morocco).

This Ksar, together with the other Ksars in the Draa-Tafilalet region were home of important Jewish communities, which, later and in very controversial and unclear conditions, immigrated to Palestine. The inhabitants of these Ksars still hold festivities in their memory. These festivities are in the form of yearly carnavals called 'Oudayn Ntaachourt.

The number of towers in ksars varies depending on the importance of the Ksar. Although each Ksar has a main gate surrounded by two towers, there is always another secondary gate used by inhabitants to access their fields and farms. Inside the Ksar, there is a big square where all the secondary "alleys" of the Ksar ramify. Each of these alleys is reserved to and leads towards the dwellings of a given family.

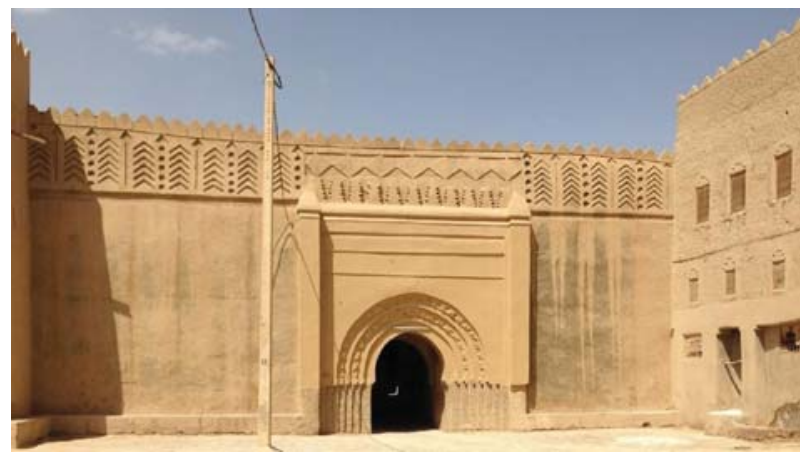

Image 2. The main entrance of the ksar

Besides the various socio-economic facilities, the Ksar contains many shops, small hotels to host foreigners and strangers who are generally traders and a place where representatives of inhabitants hold meetings to discuss the affairs and complaints brought to them. On top of that, most of the Ksars include a mosque surrounded by other facilities pertaining to it, such as the Imam's house, classrooms to teach the Qur'an and other sciences related to it.

The houses grouped inside the ksar are open on the sky and are fully closed from the outside by means of the external walls surrounding it. These houses are usually composed of two to three floors. The ground floor is usually used as a barn or zareba (a building used for sheltering animals), 
farming tools. The first floor (i.e., Lallali', on the other hand, includes the family"s living room and kitchen. The second floor is usually for guests. The construction materials are composed of palm fronds and trunks for roofing.

The walls are decorated with old Berber inscriptions and green tiles, especially the main gate of the Ksar.

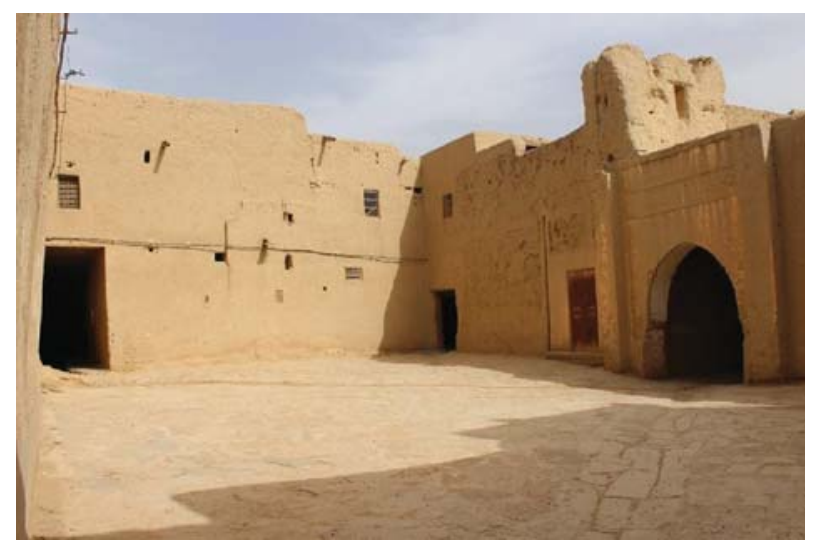

Image 3. The ksar square

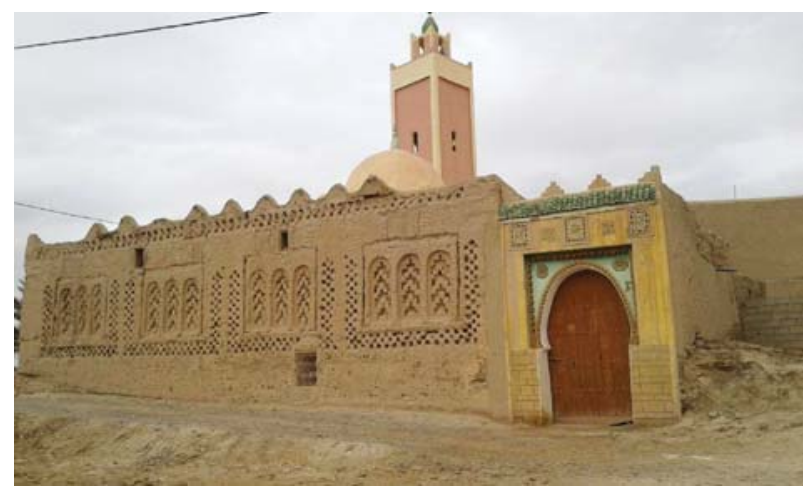

Image 4. Example of a mosque of the ksar with its minaret

They also use stones for the foundations of walls to protect them from floods and humidity.

The ksars and kasbas first appeared in the region of Tafilalet during the period of the building of Sijilmassa, the medieval city (built in 757 and disappeared in 1393) and also to other periods. All the ksar have one thing in common: the adoption of most architectural elements of cities, including 
construction materials and fundamental design. The remnants of the ruins of the medieval city of Sijilmassa (757-1393)

Although they are very few, the remnants of the ruins of the city of Sijilmassa give a clear idea on the type of architecture that characterized its glorious history, a fact which made it the concern of many scientific missions and expeditions in a bid to uncover its secrets. Excavations conducted by the Italian scientific missions in 1971, the Franco-Moroccan mission in 1974 and the American mission in 1988 and 1998 as well as the medieval resources clarified the distinguished architectural character of the city. They revealed that the city was fortified by a high and robust wall, robust gates and impregnable towers to protect it and ensure the safety of its inhabitants. They showed also that it included a variety of architectural facilities, such as congregational mosque, house of the principality, fortress, market places, factories and industries, houses, public baths and orchards. Besides, the city had complex alleyways built of clay, stone, gypsum and wood; the city knew different renovation and restoration works with the coming of the other dynasties that ruled Morocco. Because of its economic and strategic importance, it was bombarded on many occasions and subsequently destroyed in 1393. Portions of archaelogical research in the site of Sijilmassa

After the destruction of the city of Sijilmassa, its inhabitants moved to the suburbs inside ksars and kasbas which served as new shelters for them. While all the ksars and kasbas are similar in terms of their architectural design and construction materials, they are different in their demographic composition and function. We can, therefore, distinguish between the Ksar Zaouiya (related to a specific zauiya), public ksars and makhzen ksars.

- The public ksars, on the other hand, are the most dominant along the Draa-tafilalet region and are composed of different ethnic and racial groups, including:

- Berbers or Amazigh (indigenous people): they include three communities, namely Zenata, Senhaja and Mesmouda.

- Jews: Thee history of their settlement in the region is not precise; their contribution in the region's economic development, especially trade, was clearly evident.

- Arabs: the first Arab settlers arrived with the Islamic conquest during the first half of the Seventh century; the second category of Arabs includes the tribes of Banou Hilal and Banou Maaqil who came with the Almohad dynasty. The third category, however, represents the Chorafa who settled in the region during the second half of the $13^{\text {th }}$ century, more precisely in 1265, with the arrival Al Aala EL Hassan Bnou Alqasim, alias Al Dakhil, the great grandfather of the Alawite dynasty. His 
descendants managed to unify Morocco under their flag starting from the $17^{\text {th }}$ century.

- The Andalusians: The settled in the the city of Sijilmassa since its establishment.

- The slaves: They were originally from Sub-Saharan Africa.

- Al harrathoun (the tillers): A category of colored people whose skin tends towards black

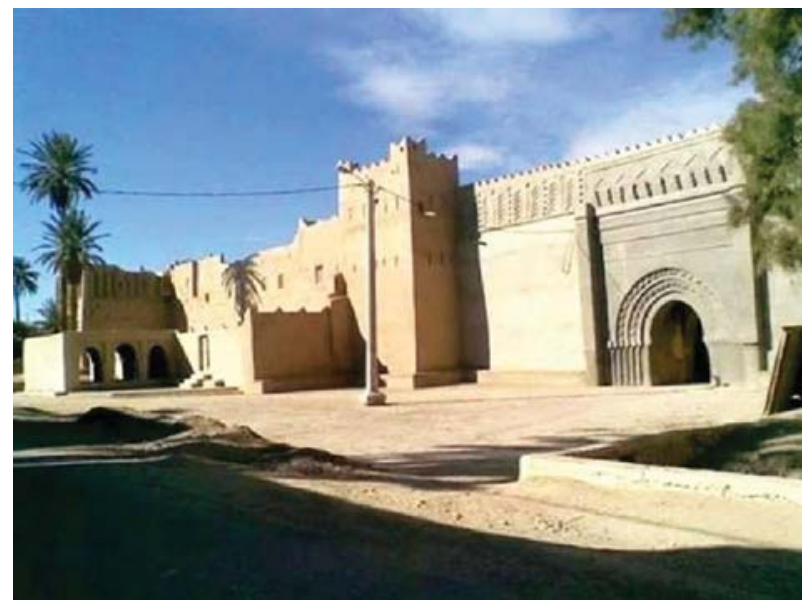

Image 5. Ksar of Mazgida, an example of the public Ksars

- The Makhzen Ksars are usually reserved for the children of the Sultans and Emirs and were built during the Alawite era (The great grand fathers of the current king of Morocco), especially Sultan Malay Ismail Hassan (1645-1727. The Ksar of Oiled Abdelhalim, one of the oldest Ksars in the city of Sijilmassa, is an example of these Makhzen Ksars:

The Ksar of Alfaida is also one of the most imporant Ksars built in Tafilalet during the Alawite era. It was built by Sultan Moulay Ismail (1645-1727) as a residence for his son Moulay Abdellah.The Main entrance of the Ksar Alfaida

It was restored during the reign of Sultan Moulay Abdelrrahman Bnou Hicham (1789-1859). From that time on, it played the leadership roles in guiding and orienting the political thrust of the regi on in so far as it served as the residence of the Sultan's representative or the Kaid (governor of a district) of the region of Tafilalet until 1956, when Morocco got its independence from French colonization. The Ksar also reflects the degree of development of architecture during the Alawite era. 


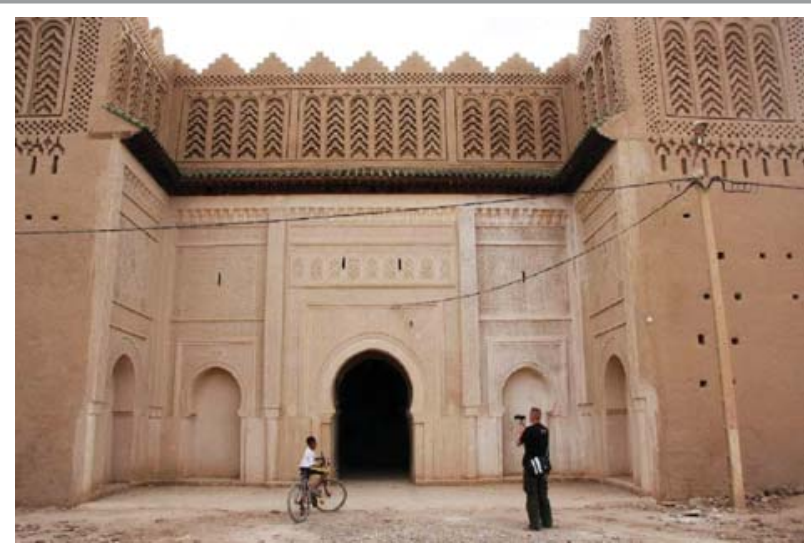

Image 6. The main entrance of the ksar of Ouled Abdelhalim

The Ksar of Lmaarka is another example of Makhzen Ksars. It was built in 1721 by the Sultan as residence for his son Moulay Cherif.

Ksars also vary in terms of their function in the sense that there are commercial or trade Ksars and artisanal ksars. The Ksars of Taboasamt and Abouam are the two most important trade or commercial ksars, Among these ksars. They competed over the trade and political leadership of Tafilalet. In 1631the competition was settled in favour of the Ksar of Abouam.

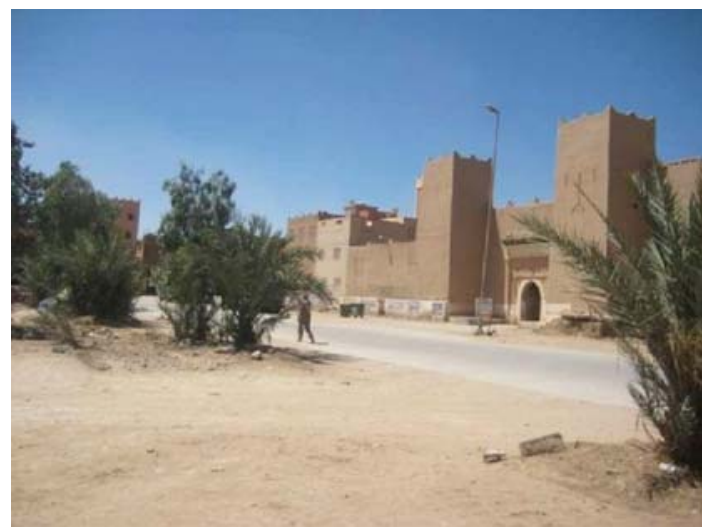

Image 7. The Ksar of Abouam

It was built by Cherif Hassani (1360-1443). After the disappearance of the city of Sijilmassa, the Ksar of Abouam became of the commercial, political, religious and intellectual centers in the region of Tafilalet. It has stood until the present day 


\section{The Ksar of Taboasamt}

It is one of the most important historical ksars built between 1393 and 1400 south of the city of the city of Sijilmassa and served as the commercial and artisanal centre as well as a centre to beat coins. It has also stood until the present day.

The Ksar of Ait Lhaj Ali, in the Todgha oasis, is also one of the most important artisanal ksars. The Ksar of Ait Lhaj Ali overlooking the Todgha Oasis

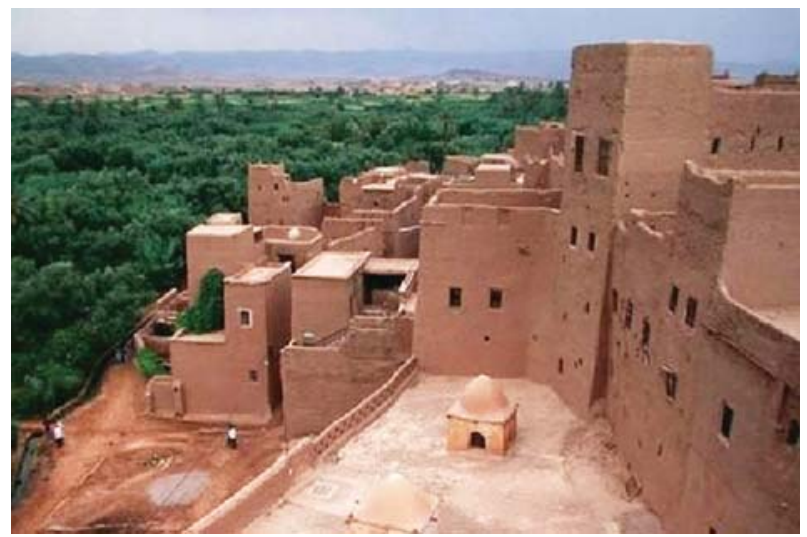

\section{Image 8. The Ksar of Ait Lhaj Ali overlooking the Todgha oasis}

Its importance lies in the fact that it was built next to Imider Silver deposit in the $14^{\text {th }}$ century. In fact, it is a historical landmark which reflects the political, economic and social role that it played. It is also a model of the co-existence that prevailed in the region between the different ethnic and religious groups, namely Berbers, Jews, Arabs and Sub Saharan Africans who came with the trade convoys and settled in the region.

Kasbas, for their part, are different from Ksars in so far as they are homes to only one family and their surface area varies depending on the demographic structure. The Kasba of Ait Ben Haddou in Ouarzazate is among the most famous Kasbas in the Draa-Tafilalet region.

The Kasbah of Ait Ben haddou was built in the 11th century during the reign of Youssef Bnou Tachafine from the Almoravid dynasty (1056-1147). The Kasba is a model of the architecture of oases in the south of Morocco and in the south-eastern mountainsides of the Atals Mountains. It represents closed, traditional residential communities. Kasbas are usually built on the hilltop and are pyramidal in shape, a fact which reflects the social hierarchy that characterized social relationships within the tribe. 


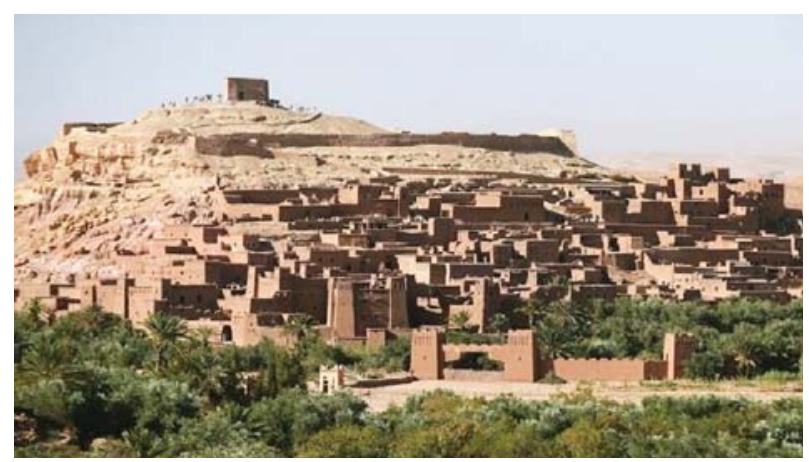

Image 9. Kasba of Ait Ben Haddou

Despite immigration, demographic transformations and the many historical events, the Kasbah of Ait Ben Haddou, unlike other Kasbas in the south east of Morocco, remained populated and inhabited. It was classified by UNESCO as global human patrimony dating as far back as the $18^{\text {th }}$ century. The Kasba receives more than 1500 tourist per year.

In addition, there is the Kasba of Taourirt in the centre of the city of Ouarzaztae.

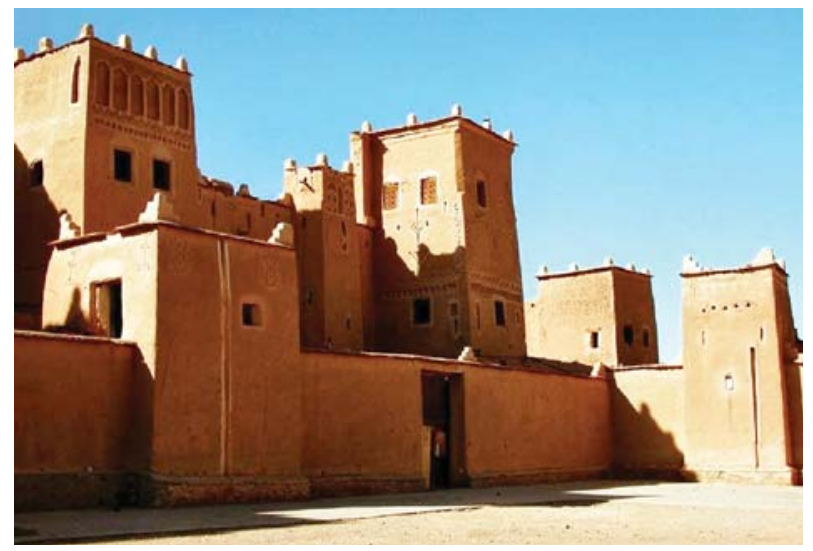

Image 10. Kasba of Taourirt

In the last decades, the architectural heritage in the region has started losing its importance due to natural factors (floods, droughts, earthquakes) and human factors (immigration, the introduction of new construction materials, such as cement and concrete, at the expense of traditional one). 
While it is true that the climatic conditions in the Draa-Tafilalet region represent natural constraints that hinder development, it is also true that they should not be taken as a geographical imperative. Instead, such conditions can be turned into advantages thanks to wise and rational human intervention.

Надійшла до редколегії 12.08.2019 р. 